\title{
The self-criticism of science
}

\author{
Alexis karpouzos ${ }^{1}$ \\ ${ }^{1}$ Affiliation not available
}

December 21, 2021

\section{Hosted file}

PhilosophyofScience.pdf available at https://authorea.com/users/451560/articles/549784-theself-criticism-of-science 